Elsevier Editorial System(tm) for Neuroscience

Manuscript Draft

Manuscript Number: NSC-10-1511R2

Title: DECREASED CCAAT/ENHANCER BINDING PROTEIN $\beta$ EXPRESSION INHIBITS THE GROWTH OF GLIOBLASTOMA CELLS

Article Type: Research Paper

Section/Category: Cellular and Molecular Neuroscience

Keywords: C/EBP $\beta$, glioblastoma, invasion, proliferation, shRNA

Corresponding Author: Professor Ana Perez-Castillo, Ph.D.

Corresponding Author's Institution: Consejo Superior de Investigaciones Científicas

First Author: Diana Aguilar-Morante, Ph.D.

Order of Authors: Diana Aguilar-Morante, Ph.D.; Marta Cortes-Canteli; Marina Sanz-SanCristobal; Angel Santos, Ph.D.; Ana Perez-Castillo, Ph.D.

Abstract: $\mathrm{C} / \mathrm{EBP} \beta$ is a leucine-zipper transcription factor implicated in the control of metabolism, development, cell differentiation, and proliferation. However, it remains unclear its role in tumor development. Here, we show that down regulation of C/EBP $\beta$ by RNA interference inhibits proliferation in the GL261 murine glioblastoma cell line, induces an arrest of the cell cycle at the G0/G1 boundary, and diminishes their transformation capacity and migration. In addition, we show that $\mathrm{C} / \mathrm{EBP} \beta$ regulates the expression of several DNA damage response- and invasion-related genes. Lastly, $\mathrm{C} / \mathrm{EBP} \beta$ depletion significantly retards tumor onset and prolongs survival in a murine orthotopic brain tumor model. Immunohistochemical analysis revealed a significant diminution of PCNA labeling in tumors derived from C/EBP $\beta$-depleted GL261 cells compared with that in controls. These results show, for the first time, the dependence of glioma cells on $C / E B P \beta$ and suggest a potential role of this transcription factor in glioma development.

Response to Reviewers: Reviewer 1

We thank the reviewer for his/her favorable comments. Regarding the inclusion of a Western blot showing the expression levels of other C/EBP family members, as we suggested in our former answers, we are now including these data in Figure 1D, showing the protein levels of two members of the C/EBP family, C/EBPalpha and C/EBP delta, in GL261 and LN18 cells. These two proteins are the ones, which have been more implicated in tumorigenesis. Accordingly, this is now commented in the text (In order to confirm the specificity of the shRNA used and to demonstrate that does not interfere or modulate by compensatory effect the expression of other members of the C/EBP family, we performed Western Blot analysis to measure the protein levels of C/EBP $\alpha$ and C/EBP $\delta$, the other two members of the family which have been implicated in tumorigenesis. As can be observed in Figure 1D, neither of them were detected in GL261 cells. LN18 cells presented some expression of C/EBP $\alpha$ and very little of C/EBP $\delta$, though their expression was similar in the control and interfered pools") (page 10, lines 17-24 of the revised manuscript)

Reviewer 2 
We certainly don't agree with the reviewer on the point that we have left the manuscript unchanged in all major points. We have answered all of the specific points of reviewer 1 and also addressed reviewer 2 main concerns. However, and following the suggestion of the editor (and now of reviewer 1 too), we have not included new experiments using a set of new cell lines. Regarding the comment on angiogenesis, we have now included in the new revised manuscript the information contained in our previous "point to point" answers relative to the genes down-regulated by C/EBP beta. In table I we have now included integrin beta 3 and vascular endothelial growth factor $\mathrm{C}$, the two other genes regulated by C/EBP beta and involved in angiogenesis. To further reinforce this point in our revised manuscript we have also added the phrases "Interestingly we also found four genes, Mcam1, Plaur, integrin beta 3 and vascular endothelial growth factor $C$, which have been implicated in promoting angiogenesis" (page 12, lines 14-16) and "The reduced vascularisation observed in those mice implanted with C/EBP $\beta$ knockdown cells, could be due, al least in part, to the down-regulation by this transcription factor of several genes involved in the promotion of angiogenesis" (page 16, lines 10-13) 
Dear Editor,

First of all thank you for giving us the opportunity to resubmit our manuscript and for your positive comments.

However, we respectfully disagree with the comment that we chose not to follow the reviewer's advice. We carefully re-read the editorial letter and our point by point replies to the reviewers and we do believe we have followed their suggestions and revised the manuscript accordingly.

We are somewhat at a loss with the statement of reviewer 2 that "the authors decided to leave the manuscript in all major points unchanged to the original version". In fact, we have modified ALL the major points as suggested by the reviewers. The only suggestion, which we have not followed is the one raised by reviewer 2 asking for the inclusion of new experiments with a different set of new cell lines. In this point we have followed the editorial suggestion that: "we do not agree with the request to carry out similar analyses on a set of new cell lines". Also, in the answer to our revised manuscript, reviewer 1 agrees with the editor as he/she states: "I do not see good reason to reproduce those studies on more cell lines than presented, including primary glioma cell lines which for most researchers are hardly accessible".

Regarding the comment of reviewer 2 concerning the possible down-regulation by C/EBP beta of some angiogenic factors, we again have to somewhat disagree with the reviewer. In our previous response to this point we commented the fact that in Table I there were two genes: Mcam1 and Plaur, which transcript levels are decreased in C/EBP beta-depleted cells and that are clearly involved in promoting angiogenesis:

(Melnikova VO et al, Bioimmunotherapy for melanoma using fully human antibodies targeting MCAM/MUC18 and IL-8. Pigment Cell Res. 2006, 19:395; Gondi CS. et al, Intraperitoneal injection of a hairpin RNA-expressing plasmid targeting urokinase-type plasminogen activator ( $u P A)$ receptor and $u P A$ retards angiogenesis and inhibits intracranial tumor growth in nude mice. Clin Cancer Res, 2007, 13: 4051. Kunigal S. et al, RNAi-mediated downregulation of urokinase plasminogen activator receptor and matrix metalloprotease-9 in human breast cancer cells results in decreased tumor invasion, angiogenesis and growth. Int J Cancer, 2007, 121:2307; Mazar AP et al, Urokinase plasminogen activator receptor choreographs multiple ligand interactions: implications for tumor progression and therapy, Clin Cancer Res, 2008, 14:5649; Liu $\mathrm{Y}$ et al, The inhibitory effect of HKa in endothelial cell tube formation is mediated by disrupting the $u P A-u P A R$ complex and inhibiting its signaling and internalization. Am $\mathrm{J}$ Physiol Cell Physiol, 2008, 295:C257; Dass K et al, Evolving role of uPA/uPAR system in human cancer. Cancer Treat Rev, 2008, 34:122).).

Besides, in our PCR-arrays we also found other genes involved in angiogenesis, such as integrin beta 3 and vascular endothelial growth factor $C$ (this was also commented in our answers) (Hayashi $\mathrm{H}$ et al, The Foxc2 transcription factor regulates angiogenesis via induction of integrin beta3 expression. J. Biol. Chem. 200, 283:23791; Su JL et al, The VEGF-C/Flt-4 axis promotes invasion and metastasis of cancer cells. Cancer Cell. 2006, 9:209). Nevertheless, to address the remark on the regulation by $\mathrm{C} / \mathrm{EBP}$ beta of some genes involved in angiogenesis, we have also 
included these later two genes in Table I. Accordingly, in our new revised version of the manuscript and in order to further comment this point, we have added the phrases "Interestingly we also found four genes, Mcam1, Plaur, integrin beta 3 and vascular endothelial growth factor $\mathrm{C}$, which have been implicated in promoting angiogenesis" (page 12, lines 14-16 of the revised manuscript) and "The reduced vascularisation observed in those mice implanted with C/EBP $\beta$ knockdown cells, could be due, al least in part, to the down-regulation by this transcription factor of several genes involved in the promotion of angiogenesis" (page 16, lines 10-13)

Regarding the request from reviewer 1 to include a Western blot showing expression levels of other C/EBP proteins, in the new revised version of the manuscript this WB has been included (Figure 1D), and accordingly we have added the statement "In order to confirm the specificity of the shRNA used and to demonstrate that does not interfere or modulate by compensatory effect the expression of other members of the C/EBP family, we performed Western Blot analysis to measure the protein levels of $\mathrm{C} / \mathrm{EBP} \alpha$ and $\mathrm{C} / \mathrm{EBP} \delta$, the other two members of the family which have been implicated in tumorigenesis. As can be observed in Figure 1D, neither of them were detected in GL261 cells. LN18 cells presented some expression of $\mathrm{C} / \mathrm{EBP} \alpha$ and very little of $\mathrm{C} / \mathrm{EBP} \delta$, though their expression was similar in the control and interfered pools", to highlight this point (page 10, lines 17-24 of the revised manuscript)

After taken into account all the points described above, and the fact that reviewer 1 thought that this paper merits publication in Neuroscience, we hope you will find this new revised version of our manuscript suitable for publication.

Yours sincerely

Prof. Ana Perez-Castillo

Corresponding author 


\section{Reviewer 1}

We thank the reviewer for his/her favorable comments. Regarding the inclusion of a Western blot showing the expression levels of other C/EBP family members, as we suggested in our former answers, we are now including these data in Figure 1D, showing the protein levels of two members of the C/EBP family, C/EBPalpha and C/EBP delta, in GL261 and LN18 cells. These two proteins are the ones, which have been more implicated in tumorigenesis. Accordingly, this is now commented in the text (In order to confirm the specificity of the shRNA used and to demonstrate that does not interfere or modulate by compensatory effect the expression of other members of the C/EBP family, we performed Western Blot analysis to measure the protein levels of $\mathrm{C} / \mathrm{EBP} \alpha$ and $\mathrm{C} / \mathrm{EBP} \delta$, the other two members of the family which have been implicated in tumorigenesis. As can be observed in Figure 1D, neither of them were detected in GL261 cells. LN18 cells presented some expression of $\mathrm{C} / \mathrm{EBP} \alpha$ and very little of $\mathrm{C} / \mathrm{EBP} \delta$, though their expression was similar in the control and interfered pools") (page 10, lines 17-24 of the revised manuscript)

\section{Reviewer 2}

We certainly don't agree with the reviewer on the point that we have left the manuscript unchanged in all major points. We have answered all of the specific points of reviewer 1 and also addressed reviewer 2 main concerns. However, and following the suggestion of the editor (and now of reviewer 1 too), we have not included new experiments using a set of new cell lines. Regarding the comment on angiogenesis, we have now included in the new revised manuscript the information contained in our previous "point to point" answers relative to the genes down-regulated by C/EBP beta. In table I we have now included integrin beta 3 and vascular endothelial growth factor $C$, the two other genes regulated by $\mathrm{C} / \mathrm{EBP}$ beta and involved in angiogenesis. To further reinforce this point in our revised manuscript we have also added the phrases "Interestingly we also found four genes, Mcam1, Plaur, integrin beta 3 and vascular endothelial growth factor C, which have been implicated in promoting angiogenesis" (page 12, lines 14-16) and "The reduced vascularisation observed in those mice implanted with C/EBP $\beta$ knockdown cells, could be due, al least in part, to the down-regulation by this transcription factor of several genes involved in the promotion of angiogenesis" (page 16, lines 10-13) 
Highlights:

1. New and important role of C/EBP $\beta$ in glioblastoma cell growth

2. Inhibition by $\mathrm{C} / \mathrm{EBP} \beta$ of glioblastoma cell invasiveness and transformation capacity.

3. Significant effect of $\mathrm{C} / \mathrm{EBP} \beta$ in growth tumor in vivo

4. Identification of several genes involved in $\mathrm{C} / \mathrm{EBP} \beta$ effects 


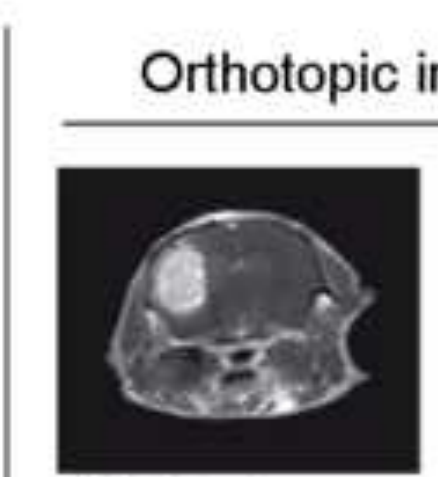

No interference

(shRNA Scramble)

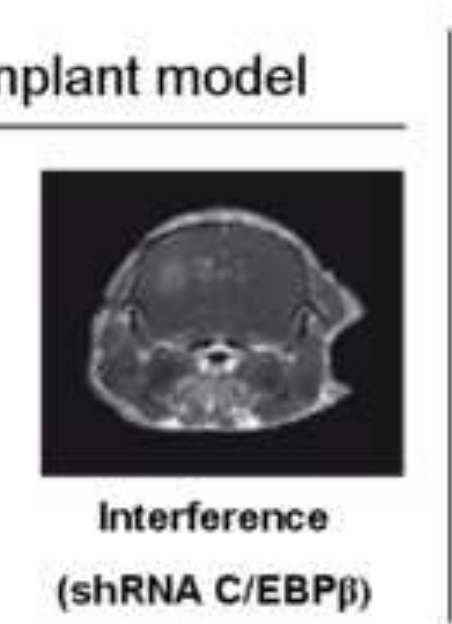

i

\section{Glioblastoma}

$\downarrow$ C/EBP $\beta$

(shRNA)

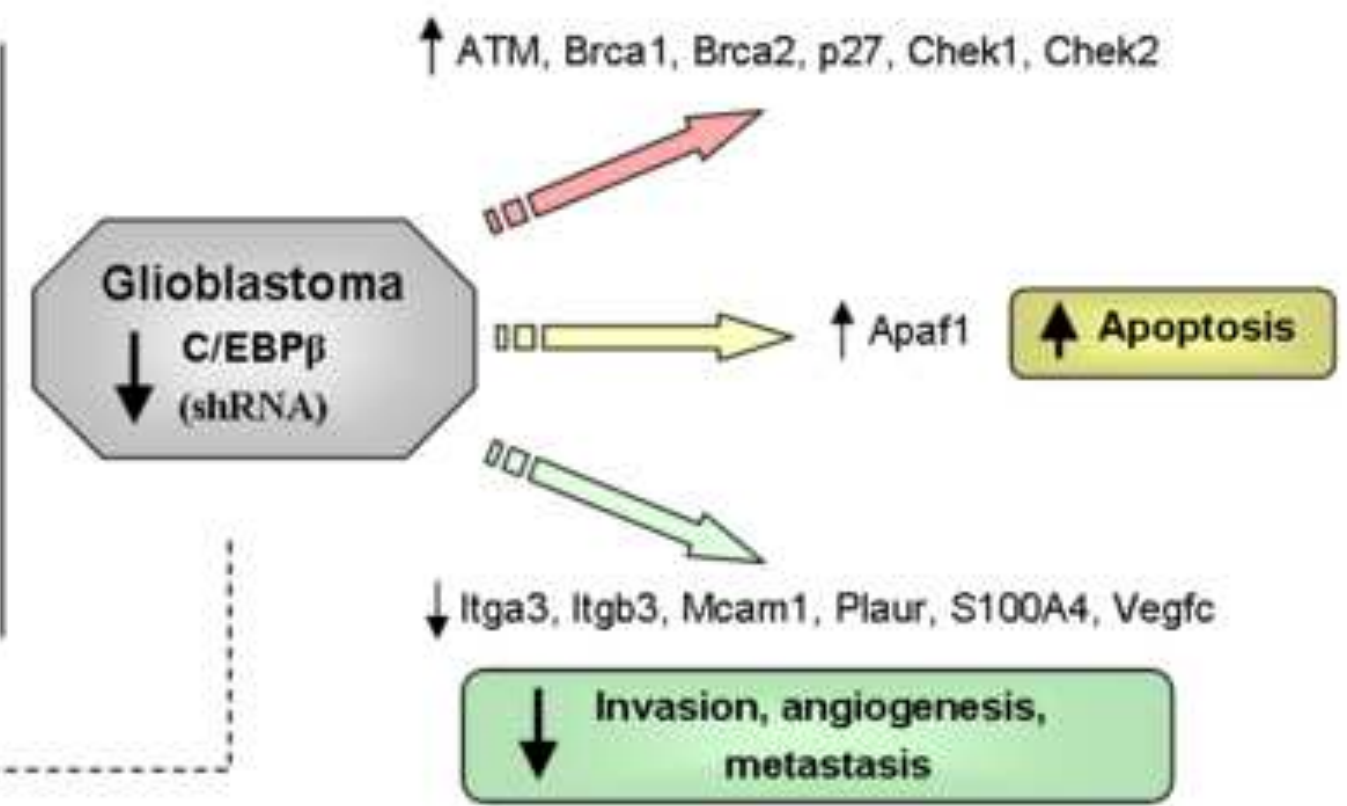


Diana Aguilar-Morante ${ }^{1}$, Marta Cortes-Canteli ${ }^{1,2}$, Marina Sanz-SanCristobal ${ }^{1}$, Angel Santos $^{3}$, Ana Perez-Castillo ${ }^{1}$.

${ }^{1}$ Instituto de Investigaciones Biomédicas, Consejo Superior de Investigaciones Científicas-Universidad Autónoma de Madrid. Arturo Duperier, 4 and Centro de Investigación Biomédica en Red sobre Enfermedades neurodegenerativas (CIBERNED), 28029-Madrid, Spain. ${ }^{2}$ Current address: Departament of Neurobiology and Genetics, The Rockefeller University, New Yok, USA. ${ }^{3}$ Departamento de Bioquímica y Biología Molecular, Facultad de Medicina, Universidad Complutense de Madrid.

Address correspondence to:

Ana Perez-Castillo. Instituto de Investigaciones Biomédicas, Consejo Superior de Investigaciones Científicas-Universidad Autónoma de Madrid. Arturo Duperier, 4. 28029-Madrid. Spain. Phone: 34-91-5854436, Fax: 34-91-5854401, E-mail: aperez@iib.uam.es

\section{CELLS \\ DECREASED CCAAT/ENHANCER BINDING PROTEIN $\beta$ EXPRESSION INHIBITS THE GROWTH OF GLIOBLASTOMA}




\begin{abstract}
$\mathrm{C} / \mathrm{EBP} \beta$ is a leucine-zipper transcription factor implicated in the control of metabolism, development, cell differentiation, and proliferation. However, it remains unclear its role in tumor development. Here, we show that down regulation of C/EBP $\beta$ by RNA interference inhibits proliferation in the GL261 murine glioblastoma cell line, induces an arrest of the cell cycle at the G0/G1 boundary, and diminishes their transformation capacity and migration. In addition, we show that $\mathrm{C} / \mathrm{EBP} \beta$ regulates the expression of several DNA damage response- and invasion-related genes. Lastly, C/EBP $\beta$ depletion significantly retards tumor onset and prolongs survival in a murine orthotopic brain tumor model. Immunohistochemical analysis revealed a significant diminution of PCNA labeling in tumors derived from C/EBP $\beta$-depleted GL261 cells compared with that in controls. These results show, for the first time, the dependence of glioma cells on $\mathrm{C} / \mathrm{EBP} \beta$ and suggest a potential role of this transcription factor in glioma development.
\end{abstract}

Keywords: C/EBP $\beta$, glioblastoma, invasion, proliferation, shRNA. 


\section{INTRODUCTION}

The CCAAT/Enhancer binding protein $\beta(\mathrm{C} / \mathrm{EBP} \beta)$ is a basic leucine zipper transcription factor (Vinson et al., 1989) involved in different cell processes including metabolism, hematopoiesis, adipogenesis, the immune response, and morphogenesis (Poli, 1998, Ramji and Foka, 2002). C/EBP $\beta$ is also expressed in the central nervous system (Sterneck and Johnson, 1998, Nadeau et al., 2005) where it plays an important role in the consolidation of long-term memory (Alberini et al., 1994, Taubenfeld et al., 2001), and cortical neuronal maturation (Menard et al., 2002). We have demonstrated that $\mathrm{C} / \mathrm{EBP} \beta$ is an important factor in neuronal differentiation (Cortes-Canteli et al., 2002) and regulates the expression of several genes involved in inflammatory processes, cancer, and brain injury (Cortes-Canteli et al., 2004). More importantly, mice lacking C/EBP $\beta$ show a reduced inflammatory response after an excitotoxic insult and are less susceptible to neuronal cell loss (Cortes-Canteli et al., 2008).

Regarding its implication in proliferation and differentiation processes, different roles have been proposed for $\mathrm{C} / \mathrm{EBP} \beta$. An antiproliferative function has been suggested in HepG2 hepatocarcinoma cells (Buck et al., 1994), epidermal keratinocytes (Zhu et al., 1999) and primary fibroblasts (Sebastian et al., 2005). Moreover, C/EBP $\beta$-knockout mice display a lymphoproliferative disorder, suggesting that $\mathrm{C} / \mathrm{EBP} \beta$ inhibits expansion of the lymphoid cell compartment (Screpanti et al., 1995). However, growth arrest induced by $\mathrm{C} / \mathrm{EBP} \beta$ appears to be highly context specific, because in several cases $\mathrm{C} / \mathrm{EBP} \beta$ displays potent growth-promoting activity. $\mathrm{C} / \mathrm{EBP} \beta$ is highly expressed in colorectal tumors (Rask et al., 2000) and is associated with ovarian tumor progression (Sundfeldt et al., 1999). Ectopic expression of C/EBP $\beta$ induces proliferation in human mammary epithelial cells (Bundy and Sealy, 2003) and macrophage tumor cells

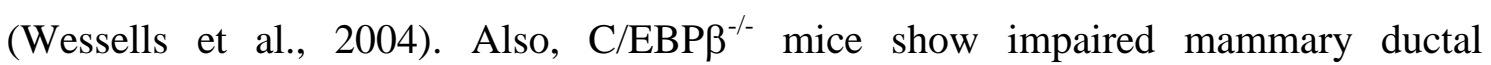
morphogenesis due to a proliferation defect (Robinson et al., 1998, Seagroves et al., 1998) and are totally resistant to carcinogen-induced skin tumor development (Zhu et al., 2002).

High-grade gliomas, which include glioblastoma (GBM) and anaplastic astrocytoma, are among the most common intrinsic brain tumors in adults and are nearly uniformly 
fatal (DeAngelis, 2001). Despite significant improvements in the early detection of malignant gliomas, the median survival of patients remains less than 12 months from the time of diagnosis (Benedetti et al., 2000, DeAngelis, 2001). Advances in glioma modeling in the mouse have made the disease amenable to in vivo functional and molecular studies (Fomchenko and Holland, 2006). However, the mechanisms underlying GBM pathogenesis and poor response to conventional therapy are yet unclear. Interestingly, it has been recently demonstrated that $\mathrm{C} / \mathrm{EBP} \beta$ expression is markedly increased in high-grade glioma compared with low-grade glioma, and low expression in tumor tissue correlates with longer patient survival (Homma et al., 2006).

All these data has prompted us to investigate whether $\mathrm{C} / \mathrm{EBP} \beta$ is involved in glioblastoma development. Here, we present evidence that $\mathrm{C} / \mathrm{EBP} \beta$ is strongly expressed in glioma cells. Furthermore, reduction of C/EBP $\beta$ levels inhibits glioblastoma cell growth in vitro and in vivo. The demonstration that $\mathrm{C} / \mathrm{EBP} \beta$ is a critical positive regulator of glioma growth will provide new targets for the development of future brain tumor treatments 


\section{MATERIALS AND METHODS}

\section{Construction of small interfering RNAs and Stable transfection}

GL261 murine glioblastoma cells were obtained from the NCI-Frederick Cancer Research Tumor Repository (Frederick, MD) and propagated in RPMI medium with 10 $\%$ fetal bovine serum as described (El Andaloussi et al., 2006). To knockdown C/EBP $\beta$ expression, siRNA against two different target sites of mouse C/EBP $\beta$ and a nontargeting siRNA control were obtained from Dharmacon (Thermo Scientific, Waltham, MA). The interfering selected sequences were 5'-GAG CGA CGA GTA CAA GAT G3' (pool I4) and 5' -CCT TTA GAC CCA TGG AAG TTT- 3' (pool I5). The oligonucleotides were annealed and the double-stranded oligonucleotides were cloned into pSilencer 4.1 vector (Ambion, Austin, TX), in which shRNAs were expressed under the control of the CMV promoter. The plasmids were transfected into GL261 glioblastoma cells by using Lipofectamin 2000 (Invitrogen, CA) and stable transfectans were selected using $400 \mu \mathrm{g} / \mathrm{ml}$ of G418 and maintained in this selection medium. Pools C1 (expressing a non-targeting shRNA control) and I4 (expressing a shRNA against C/EBP $\beta$ ) were used throughout the study. LN18 human glioblastoma cells were obtained from Dr. Peinado (Department of Cell and Developmental Biology, Cornell University) and maintained in DMEM medium with $10 \%$ fetal bovine serum, $2 \mathrm{mM}$ Glutamine, $100 \mu \mathrm{g} / \mathrm{ml}$ penicillin and $100 \mu \mathrm{g} / \mathrm{ml}$ streptomycin. Human C/EBP $\beta$ expression was silenced in LN18 cells using the FUGW lentiviral vector. The interfering selected sequence was: 5'- GAA GAC CGT GGA CAA GCA C -3' (pool FC1). A non-targeting sequence (5'- GCC GCT TTG TAG GAT AGA G -3', pool FS) was also used. These lentiviral vectors were obtained from Dr. Quintanilla-Martinez. For lentiviral infections of LN18 cells, 293T cells were transiently transfected with the appropriate lentiviral expression vector and the vectors pMD2-G, pMDLg/pRRE, and pRSV-Rev, which encode lentiviral proteins. The medium containing lentiviruses was recovered, filtered through a $0.45-\mu \mathrm{m}$ filter and added to the recipient cells. The same procedure was repeated $8 \mathrm{~h}$ and $24 \mathrm{~h}$ later. Pools FS (expressing a non targeting shRNA) and FC1 (expressing a shRNA against C/EBP $\beta$ ) were used in this study. 


\section{Immunoblot analysis}

Cultured cells were harvested and lysed in ice-cold RIPA buffer and equal quantities of total protein were separated by $12 \%$ SDS-PAGE. After electrophoresis, proteins were transferred to nitrocellulose membranes (Protran, Whatman, Dassel, Germany) and blots were probed with the indicated primary antibodies, as previously described (CortesCanteli et al., 2004). The antibodies used were the following: goat polyclonal $\mathrm{C} / \mathrm{EBP} \alpha$, rabbit polyclonal anti-C/EBP $\beta$, rabbit polyclonal anti-C/EBP $\delta$ rabbit polyclonal antiBrca1, rabbit polyclonal anti-p27 (Santa Cruz Biotechnology, CA, U.S.A.), mouse monoclonal anti- $\alpha$-tubulin (Sigma), mouse monoclonal anti-ATM (Novus Biologicals, Littleton, CO, U.S.A.) and mouse monoclonal anti-Chk2 (Millipore, Billerica, MA, U.S.A.) antibodies. Secondary peroxidase-conjugated donkey anti-rabbit and rabbit anti-mouse antibodies were from Amersham Biosciences (GE Healthcare, Buckinghamshire, England) and Jackson Immunoresearch, respectively.

\section{Proliferation assays and cell cycle studies}

The effect of C/EBP $\beta$ expression on cell proliferation was determined using the nonradioactive BrdU-based cell proliferation assay (Roche) according to the manufacturer's protocol. Cells were seeded in triplicate onto 96-well plates at a density of 2,000 cells/well. After $24 \mathrm{~h}$ of growth, $10 \mu \mathrm{M}$ BrdU was added and cells were cultured for another $16 \mathrm{~h}$. BrdU incorporation into the DNA was determined by measuring the absorbance at both 450 and $690 \mathrm{~nm}$ on an ELISA plate reader. BrdU incorporation was also analyzed by immunofluorescence analysis, and the number of stained cells was counted using the Image J program.

Cell viability was measured using the MTT assay (Roche Diagnostic, $\mathrm{GmbH}$ ), based on the ability of viable cells to reduce yellow MTT to blue formazan. Briefly, cells were cultured in 96-well microtitre plates for various periods of time, then cells were incubated with MTT $(0.5 \mathrm{mg} / \mathrm{ml}, 4 \mathrm{~h})$ and subsequently solubilized in $10 \% \mathrm{SDS} / 0.01 \mathrm{M}$ $\mathrm{HCl}$ for $12 \mathrm{~h}$ in the dark. The extent of reduction of MTT was quantified by absorbance measurement at $550 \mathrm{~nm}$ according to the manufacturer's protocol.

For analysis of progression through the cell cycle cells were fixed in 70\% ethanol/PBS, pelleted and resuspended in buffer containing $10 \mu \mathrm{g} / \mathrm{ml}$ RNAse and $0.003 \%$ propidium iodide, as previously described (Pignatelli et al., 2001). Cell cycle distribution was determined by flow cytometric analysis utilizing a Cyan MLE-R Cytometer (DAKO- 
Cytomation, Glastrup, Denmark). Data analysis was performed using the Summit Software (DAKO).

\section{Soft agar colony formation assay}

To perform anchorage-independent growth assays, 50,000 cells were resuspended in 1 $\mathrm{ml}$ of $0.7 \%$ agar in tissue culture medium containing $10 \%$ serum in $60 \mathrm{~mm}$ plates over a bottom layer of $1 \%$ agar in medium. The cells were allowed to grow for 21 days with weekly refeeding. Colonies were stained with p-iodotetrazolium violet and 20 randomly selected fields were photographed under a phase-contrast microscope (10x magnification). Colonies were then counted, and the mean number of colonies per plate was calculated. All experiments were done in triplicate.

\section{Cell invasion, migration and wound healing assay}

Tumor cell invasion assays were performed using Transwell chambers with $12-\mu \mathrm{m}$ pores (Costar) coated with a layer of Matrigel free of growth factors (Collaborative Biomedical). Medium with $20 \%$ fetal bovine serum was added to the lower chambers of the Transwells. I4 or C1 cells $(50,000)$ were seeded on top of the Transwell in triplicate in medium without serum and incubated at $37^{\circ}$ for $48 \mathrm{~h}$. The bottom filters were fixed and stained with DAPI at the end of the experiments. Cells in the top chambers were removed by wiping with cotton swabs, and the stained cells that had migrated through the Matrigel were counted under a microscope. Ten randomly selected 20x microscopic fields were counted. Wound healing assay was used to detect the alteration of cell motility. I4, C1, FS and FC1 cells were seeded onto 60-mm plates and, after overnight incubation, an artificial wound was created using P200 pipette tip to scratch on the confluent cell monolayer. Photomicrograph was taken immediately (time $0 \mathrm{~h}$ ), so that the migrating cells and closing of scratch wound could be observed. Microphotograhs were also taken at 24 and $48 \mathrm{~h}$ post wounding. Within each assay the experiments were performed in triplicates.

\section{PCR-Array}

Total RNA was extracted from C1 and I4 pools by using TRIzol (Invitrogen, Carlsbad, CA). Genomic DNA contamination was eliminated by Dnase treatment and C/EBP $\beta$ expression was tested by PCR before starting PCR-Array procedure. Mouse Cancer and Cell Cycle RT Profiler PCR Arrays were purchased from SuperArray Bioscience 
Corporation (Frederick, MD). PCR was performed on ABI Prism 7700 Sequence Detector (Applied Biosystems). Data were analyzed using the DDCt method and the housekeeping genes HPRT1, GAPDH, and $\beta$-actin for normalization. For each gene fold-changes were calculated as difference in gene expression between $\mathrm{C} 1$ and $\mathrm{I} 4$ pools.

\begin{abstract}
Animal Experiments
Adult male C57BL/6 mice ( $n \geq 7$ per group) were anaesthetized by intraperitoneal injection of ketamine $(60 \mathrm{mg} / \mathrm{Kg})$ and medetomidine $(0.125 \mathrm{mg} / \mathrm{Kg})$ and positioned in a stereotaxic apparatus (Kopf Instruments, CA). To establish intracranial tumors I4 or C1 cells $(100,000$ cells) were implanted unilaterally into the left hemisphere using the following coordinates from Bregma: posterior $-1.06 \mathrm{~mm}$; lateral $-3 \mathrm{~mm}$ and a depth of 3 mm, according to the atlas of Paxinos and Franklin (Paxinos and Franklin, 2001). The mice were then housed individually to recover. All procedures with animals were carried out in accordance with the protocols issued by the 'Ethics Committee for Animal Experimentation' of the Instituto de Investigacones Biomédicas (CSIC-UAM), which followed National (normative 1201/2005) and International recommendations (normative 86/609 from the European Communities Council). Special care was taken to minimize animal suffering.
\end{abstract}

\title{
Magnetic Resonance Imaging
}

Magnetic Resonance Imaging (MRI) was performed using an MRI scanner (Bruker PharmaScan 7.0T, 16 cm; Bruker Medical Gmbh, Ettlingen, Germany). Mice brain MRI was performed with a $90 \mathrm{~mm}$ gradient insert and a concentrical $38 \mathrm{~mm}$ birdcage resonator, using Paravision v4.0 software (Bruker Medical Gmbh, Ettlingen, Germany) as implemented in a Hewlett-Packard console, operating on a Linux platform. MRI examinations used adult male C57BL/6 mice ( $n \geq 7$ per group) anaesthetized through a plastic mask with $2 \%$ isofluorane in $99.9 \% \mathrm{O}_{2}$. Animals were allowed to breath spontaneously during the experiment and were placed in a heated cradle to maintain the core body temperature at approx. $37^{\circ} \mathrm{C}$. The physiological state of the animal was monitored throughout MRI acquisition through the respiratory rate using a Biotrig physiological monitor (Brucker). Gadolinium-DTPA-enhanced $\mathrm{T}_{1}$-weighted spin-echo images were acquired at 11, 15, and 18 days after injection with a Rapid Acquisition with Relaxation Enhancement (RARE) (Hennig et al., 1986) sequence in axial orientations (TR: $350 \mathrm{~ms}$, TE: $10.6 \mathrm{~ms}$, averages: 4, FOV: $2.30 \mathrm{~cm}$, acquisition matrix: 
256×256, slice thickness: $1.00 \mathrm{~mm}$, number of slices: 16). The in vivo spectroscopy protocol acquired two $3 \times 3 \times 3 \mathrm{~mm}$ voxels in the striatal area, using a Point-Resolved Spatially Spectroscopy (PRESS) (Bottomley, 1987) protocol, combined with VAPOR water suppression, (Tkac et al., 1999)(TR: $3000 \mathrm{~ms}$, TE: $35 \mathrm{~ms}$, averages: 128). The tumor area was calculated from $\mathrm{T}_{1}$-weighted images using image $\mathrm{J}$ analysis software. Tumor volume was estimated from the summation of tumor areas on each slice, multiplied by slice thickness.

\section{Histology and Immunohistochemistry}

Formalin-fixed, paraffin-embedded sections $(4 \mu \mathrm{m})$ from tumors were deparaffinized in xylene, rehydrated in a graded series of alcohols, and rinsed in distilled water. All immunohistochemistry analysis were performed as previously described (Luna-Medina et al., 2007). The proliferative activity of the tumor was assessed with anti-PCNA antibody.

\section{Statistics}

Other than the survival experiments, Student's test was used to analyze statistical differences between the different groups. Survival curves were plotted with KaplanMeier method and survival for the two groups of animals was studied using log-rank test. Differences were considered statistically significant at $p<0.05$. 


\section{RESULTS}

\section{Effect of C/EBP $\beta$ depletion on GL261 cell proliferation and viability.}

We first analyzed the basal level of expression of C/EBP $\beta$ in murine GL261 glioblastoma cells. Our results showed increased C/EBP $\beta$ expression in contrast to primary astrocytes, and these levels were very similar to those present in lipopolisaccharide-activated astrocytes (Fig. 1A). To investigate the cellular action of the C/EBP $\beta$ protein in GL261 cells, we stably introduced a pSilencer vector encoding shRNA for C/EBP $\beta$ or non-targeting shRNA (see "Materials and Methods"), and different geneticin-resistant pools were tested for C/EBP $\beta$ expression using an antibody specific for C/EBP $\beta$. We evaluated the efficacy of shRNA transfection in the silencing of gene expression of C/EBP $\beta$ by using Western blot analysis. The immunoblot in Figure 1B shows that in two of these interfered pools, I4 and I5, the content of C/EBP $\beta$ protein decreased approximately $75 \%$, as compared to control $\mathrm{C} 1$ and $\mathrm{C} 2$ pools. For this reason we selected the $\mathrm{I} 4$ and $\mathrm{C} 1$ pools for subsequent studies. Figure $1 \mathrm{C}$ shows a dramatic decrease in the protein levels of C/EBP $\beta$ in the human LN18 cells expressing the shRNA for this mRNA (FC1) compared to control cells expressing a non-target sequence (FS). In order to confirm the specificity of the shRNA used and to demonstrate that does not interfere or modulate by compensatory effect the expression of other members of the C/EBP family, we performed Western Blot analysis to measure the protein levels of $\mathrm{C} / \mathrm{EBP} \alpha$ and $\mathrm{C} / \mathrm{EBP} \delta$, the other two members of the family which have been implicated in tumorigenesis. As can be observed in Figure 1D, neither of them were detected in GL261 cells. LN18 cells presented some expression of C/EBP $\alpha$ and very little of $\mathrm{C} / \mathrm{EBP} \delta$, though their expression was similar in the control and interfered pools.

We next investigated whether glioma cell proliferation is directly affected by C/EBP $\beta$. Although downregulation of C/EBP $\beta$ in glioma cells did not alter cell morphology (data not shown), proliferation, as measured by BrdU incorporation and subsequent ELISA analysis (Fig. 2A) was decreased to $50 \%$ in the I4 pool compared with control cells. These results were similar to those obtained with the I5 pool. This growth inhibitory effect was further confirmed by BrdU immunocytochemical analysis (Fig. 2B). Additionally, cell viability, measured by the MTT assay, was significantly diminished 
in the I4 pool, compared to its $\mathrm{C} 1$ control pool (Fig. 2C). This decrease in cell viability FS cells. These data show that $\mathrm{C} / \mathrm{EBP} \beta$ plays a vital role in maintaining glioblastoma cell proliferation. To better understand the nature of the growth retardation associated with decreased expression of $\mathrm{C} / \mathrm{EBP} \beta$, we next performed cell cycle analysis. The proportion of cells at specific stages of the cell cycle was determined by flow cytometry. It was observed (Fig. 2D) that the cell cycle profiles of I4 cells were significantly altered, with a block at the G0/G1 boundary, less cells progressing through the S-phase than the control C1 cells and a concomitant decline in the number of cells in G2/M phase. We also observed an increased in the sub-G0/G1 subpopulation suggesting an increase in the number of apoptotic cells in the pool I4 with lower expression of $\mathrm{C} / \mathrm{EBP} \beta$. The ability of cancer cells to grow without adhering to extracellular matrix proteins (anchorage-independent growth) correlates closely with their ability to form malignant tumors. Anchorage-independent growth presumably allows the cells to invade and metastasize, characteristics that distinguish malignant from benign tumors. Thus, to assess the effect of C/EBP $\beta$ expression on anchorage-independent growth of GL261 cells, we seeded C1 and I4 cells in medium containing $0.7 \%$ agar, and counted colonies 21 days later. As shown in Figure 2E, we observed a significant reduction in the number of the colonies of C/EBP $\beta$ knock down cells compared with controltransfected cells $(45 \pm 7$ and $120 \pm 9$ colonies/plate, respectively; $* * * p \leq 0.001)$. Hence, depletion of C/EBP $\beta$ expression partially inhibited the anchorage-independent growth of GL261 cells.

\section{C/EBP $\beta$ depletion inhibits glioblastoma motility and invasion.}

The ability of glioblastoma cells to invade into normal surrounding tissue is influenced by their motility as well as ability to penetrate through tissue barriers such as extracellular matrix. To assess the role of C/EBP $\beta$ in glioblastoma cell motility, we used "scratch-wound" assays. These assays showed that both murine GL261 cells and human LN18 cells depleted of C/EBP $\beta$ did not fill in a scratch as rapidly as cells treated with a control RNA duplex, suggesting decreased cell motility (Fig. 3A). To further substantiate these findings, we also assessed glioblastoma cell motility using Transwell chambers. In these assays, control cells and cells depleted of C/EBP $\beta$ are replated into Transwell chamber membranes coated with Matrigel at the same density and $48 \mathrm{~h}$ later 
the numbers of cells that have crossed the chamber membrane are counted. Depletion of C/EBP $\beta$ in GL261 cells (I4 and I5 pools) resulted in a significant decrease in the number of cells that crossed the Matrigel-coated membranes, indicating a true decrease in motility and invasive ability (Fig. 3B).

To further analyze the mechanism involved in the stimulatory effect of C/EBP $\beta$ on GL261 glioblastoma cells, we studied the expression of genes implicated in these processes. To this end we screened two arrays of cell cycle and cancer-related genes. As shown in Table I, among other, we found a number of genes involved in the DNA damage response, such as ATM, Brca1, Brca2, Chk1, Chk2, and p27, that were significantly up-regulated in the I4 C/EBP $\beta$-deficient cells (Table I). In contrast, we found that the expression of a substantial number of genes involved in adhesion invasion, and metastasis, including integrin $\alpha 3$, melanoma cell adhesion molecule, plasminogen activation urokinase receptor, and S100 calcium binding protein A4, was down-regulated in I4 cells. Interestingly we also found four genes, Mcam1, Plaur, integrin beta 3 and vascular endothelial growth factor $\mathrm{C}$, which have been implicated in promoting angiogenesis. We next assessed these C/EBP $\beta$-induced changes of the expression of the genes involved in the DNA damage response at the protein level. We found that, according with the PCR-array data, the abundance of all of them was significantly increased in the interfered lines (Fig. 4), suggesting that the observed effects of C/EBP $\beta$ interference could be mediated by it effects upon the G0/G1 checkpoint, and an impairment in the progression through the cell cycle with a concomitant inhibition of glioblastoma progression.

Knockdown of C/EBP $\beta$ inhibits the growth of GL261 glioma cells in vivo. Based on the above in vitro findings, C/EBP $\beta$ appears to be important in the growth of glioblastoma cells. To investigate whether the effects of C/EBP $\beta$ knockdown on glioblastoma growth inhibition are sustained in vivo, we next orthotopically implanted GL261 glioma cells into mice brains to generate tumors. The murine glioma GL261 model has been the most common used syngeneic transplant model for both subcutaneous and intracranial experimental glioma tumors (Miyatake et al., 1997, Kjaergaard et al., 2000, Edwards et al., 2002). This particular intracranial animal model recapitulates many of the histopathological and biological features of human glioma 
including both necrosis with pseudopalisading and invasion of the brain adjacent to tumor as isolated single cells and as group of cells around vascular channels (Zagzag et al., 2003). To control for equal tumor loading, we monitored tumor growth in vivo by magnetic resonance imaging (MRI) at different times after implantation. Mice injected with $\mathrm{C} / \mathrm{EBP} \beta$-deficient cells also showed a delayed onset and progression of tumors compared to $\mathrm{C} 1$ controls and tumor volume, as assessed by $\mathrm{T}_{1}$-weighed images after gadolinium contrast administration, revealed a significant reduction in tumor volume in mice implanted with C/EBP $\beta$-deficient I4 cells (Fig. 5A, B). About $85 \%$ reduction in tumor volume was observed in I4-derived tumors at 15 days post-injection. This strong reduction in the tumor growth potential induced by $\mathrm{C} / \mathrm{EBP} \beta$ interference was maintained over time. Both the log-rank test and Kaplan-Meier analysis of the survival data demonstrated a significant survival advantage for the C/EBP $\beta$ low expression glioma-bearing mice when compared to their matched C/EBP $\beta$ high expression parental glioma-bearing animals (Fig. 5C). Log-rank analysis of the data yielded a $p$ value of 0.0012. Mice injected with I4 cells presented a significant increase in the mean survival (41 versus 26.5 days).

Because the C/EBP $\beta$-deficient tumors arose at a later time point, we anticipated that they would differ histologically and possibly also in terms of malignancy. Here, a difference between C1- and I4-derived tumors became apparent. Although both I4 and $\mathrm{C} 1$ pools gave rise to gliomas, which according to pathologists could be classified as grade IV glioblastoma, C/EBP $\beta$-deficient tumors did not show blood vessels formation or multinucleated giant cells, typical features of aggressive grade IV glioblastomas (Fig. 5D). Also, we did not detect necrosis areas in tumors derived from I4 cells, in comparison with $\mathrm{C} 1$-derived tumors, 18 days after injection. In addition, the PCNA labeling, a measure of proliferation, of I4-derived tumors, was significantly less than that of the $\mathrm{C} 1$ tumors (Fig. 5E), again suggesting a growth-suppressing action of $\mathrm{C} / \mathrm{EBP} \beta$ on tumor cells in vivo. 


\section{DISCUSSION}

Glioblastoma multiforme is the most common form of brain tumor occurring in adults. This devastating disease is usually incurable and patients have a mean survival time of approximately 1 year after diagnosis (Benedetti et al., 2000, DeAngelis, 2001). Here, we show that $\mathrm{C} / \mathrm{EBP} \beta$ has a role in promoting glioblastoma growth in vitro and in vivo. The C/EBP $\beta$ gene has been shown to promote both growth arrest and increased proliferation in a context-specific manner. How it stimulates mitotic growth and why it elicits completely opposite effects on proliferation in different cellular contexts remains to be ascertained. In this study, we show for the first time that depletion of C/EBP $\beta$ expression suppresses glioma cell growth in vitro and glioma tumor growth in vivo. This was accompanied by a regulation of the expression of different genes involved in DNA damage response and in invasion and metastasis. Collectively, our findings suggest that C/EBP $\beta$ might play an important role as a growth regulator in high-grade gliomas opening out a new role for $\mathrm{C} / \mathrm{EBP} \beta$ in the pathogenesis of central nervous system tumors.

We have focused our work on the study of the oncogenic role of C/EBP $\beta$ in glioma. We have found that a high $\mathrm{C} / \mathrm{EBP} \beta$ level is a poor prognosis marker, supporting that $\mathrm{C} / \mathrm{EBP} \beta$ is acting as an oncogenic factor in glioblastomas and has an important role in their progression. Although $\mathrm{C} / \mathrm{EBP} \alpha$, another member of the $\mathrm{C} / \mathrm{EBP}$ family, has emerged as a clear negative regulator of cell proliferation in many cellular contexts raising the possibility that could function as a tumor suppressor (Schuster and Porse, 2006), the function of $\mathrm{C} / \mathrm{EBP} \beta$ upon proliferation, in situations where the function of $\mathrm{C} / \mathrm{EBP} \alpha$ is straightforward, is more complex. Several data suggested that $\mathrm{C} / \mathrm{EBP} \beta$ might work as an anti-proliferative agent. $\mathrm{C} / \mathrm{EBP} \beta$, similarly to $\mathrm{C} / \mathrm{EBP} \alpha$, is able to suppress cell proliferation through repression of E2F target-genes in a manner dependent on members of the retinoblastoma protein family (Sebastian et al., 2005). Also, C/EBP $\beta$ expression has been associated with growth arrest of keratinocytes (Zhu et al., 1999) and induction of cell cycle exit induced by Ras ${ }^{\mathrm{V} 12}$ in primary cells (Hanlon and Sealy, 1999, Shuman et al., 2004). However, and in agreement with our results, other studies have suggested a growth-promoting activity for C/EBP $\beta$. Zhu et al (Zhu et al., 2002) have shown that $\mathrm{C} / \mathrm{EBP} \beta^{-/-}$mice are completely refractory to skin tumorigenesis 
induced by the carcinogen 7,12-dimethyl-benz[a]anthracene, that produce oncogenic ras mutations in epidermal keratinocytes, suggesting an important role for $\mathrm{C} / \mathrm{EBP} \beta$ in keratinocytes survival in response to oncogenic ras and in skin tumorigenesis (Sterneck et al., 2006). C/EBP $\beta$ also functions as a survival factor in myc/ras transformed macrophages in vitro (Wessells et al., 2004) and in Wilms tumor cells (Li et al., 2005) and has been associated with ovarian tumor progression (Sundfeldt et al., 1999).

Here, we show that C/EBP $\beta$ exerted a stimulatory effect on murine and human glioblastoma cell proliferation and viability in vitro. Inhibition of C/EBP $\beta$ expression leads to G1 arrest and reduced S phase in GL261 cells. These effects are accompanied by an increase in the expression of several genes involved in the DNA damage response, such as ATM, Brca1, Brca2, Chk1, Chk2, and p27, thereby ensuring a nonproliferative outcome. These results provide support for the possibility that depletion of $\mathrm{C} / \mathrm{EBP} \beta$ inhibits cell proliferation and survival in glioblastoma cells by directly affecting the expression of these genes resulting in an activation of the G0/G1 checkpoint, and impairment in the progression through the cell cycle and consequently an inhibition of glioblastoma progression in vivo. Consistent with this proposal, the regulatory regions of all these genes present consensus binding sites for C/EBP $\beta$, suggesting that this protein can indeed directly regulate their expression. Also, and in agreement with our results, it has been shown that overexpression of $\mathrm{C} / \mathrm{EBP} \beta$ in a human mammary epithelial cell line leads to anchorage independent growth and invasive properties (Bundy and Sealy, 2003). We show here that a decrease in C/EBP $\beta$ expression leads to an inhibition of colony growth in soft agar, suggesting that C/EBP $\beta$ plays a role in the oncogenic process of anchorage-independence and is critical for tumor growth in glioblastoma. In this regard, results from the PCR array analysis also show that $\mathrm{C} / \mathrm{EBP} \beta$ depletion decreases the mRNA levels of different genes involved in invasiveness and metastasis, including integrin $\alpha 3$, melanoma cell adhesion molecule, plasminogen activation urokinase receptor, and S100 calcium binding protein A4, suggesting that the induction of these genes by $\mathrm{C} / \mathrm{EBP} \beta$ could mediate its effects on these processes.

Notably, it has recently been demonstrated that expression of C/EBP $\beta$ is markedly increased in high-grade glioma compared with low-grade glioma, and patients whose 
expression of $\mathrm{C} / \mathrm{EBP} \beta$ in tumor tissue was lower survived longer than those whose expression was higher (Homma et al., 2006). These results are consistent with our data showing that $\mathrm{C} / \mathrm{EBP} \beta$ knockdown inhibited glioblastoma tumor growth in vivo. Consequently, tumor development was significantly delayed in mice injected with I4 cells. Our data clearly show that those mice bearing GL261 cells with high C/EBP $\beta$ expression had poorer survival than mice bearing $\mathrm{C} / \mathrm{EBP} \beta$-deficient tumors $(p=$ 0.0012). Moreover, $\mathrm{C} / \mathrm{EBP} \beta$-silenced glioblastoma lacked the aggressiveness of control tumors, including enhanced blood vessel formation and abundance of giant cells, suggesting that in addition to proliferation, $\mathrm{C} / \mathrm{EBP} \beta$ signaling is also an effective regulator of malignant transformation in glioblastoma cells in vivo. The reduced vascularisation observed in those mice implanted with $\mathrm{C} / \mathrm{EBP} \beta$ knockdown cells, could be due, al least in part, to the down-regulation by this transcription factor of several genes involved in the promotion of angiogenesis. This lends support to the view that dysregulated C/EBP $\beta$ expression could influence glioblastoma development. Our results are supported by a recent paper demonstrating that expression of $\mathrm{C} / \mathrm{EBP} \beta$ is linked to the mesenchymal state of primary glioblastoma and provide an excellent prognostic biomarker for tumor aggressiveness (Carro et al.).

In conclusion, our study demonstrates that $\mathrm{C} / \mathrm{EBP} \beta$ is a crucial regulator of glioblastoma cell growth and transformation and that several genes involved in DNA repair, invasion and metastasis may be important downstream effectors of C/EBP $\beta$ mediated oncogenic properties. These findings are clinically relevant because advancedstage glioblastomas are refractory to current treatments; thus, understanding C/EBP $\beta$ regulation of tumor growth potential, could provide a novel therapeutic adjunct for aggressive glioblastomas. 


\section{ACKNOWLEDGMENTS}

This work was supported by the Ministerio de Educacion y Ciencia grant SAF200762811 (to A.P.-C). CIBERNED is founded by the Instituto de Salud Carlos III. D.A.-M is a fellow of the Consejo Superior de Investigaciones Científicas. We would like to thank Dr. J. Dorado for his help with the flow cytometry analysis. We also thank Dr. Qintanilla-Martinez (Institute of Pathology, German Research Center for Environmental Health, Germany) for providing the shC/EBP $\beta$ lentiviral plasmid. 


\section{REFERENCES}

Alberini CM, Ghirardi M, Metz R, Kandel ER (C/EBP is an immediate-early gene required for the consolidation of long-term facilitation in Aplysia. Cell 76:1099-1114.1994).

Benedetti S, Pirola B, Pollo B, Magrassi L, Bruzzone MG, Rigamonti D, Galli R, Selleri S, Di Meco F, De Fraja C, Vescovi A, Cattaneo E, Finocchiaro G (Gene therapy of experimental brain tumors using neural progenitor cells. Nat Med 6:447-450.2000).

Bottomley PA (Spatial localization in NMR spectroscopy in vivo. Ann N Y Acad Sci 508:333348.1987).

Buck M, Turler H, Chojkier M (LAP (NF-IL-6), a tissue-specific transcriptional activator, is an inhibitor of hepatoma cell proliferation. Embo J 13:851-860.1994).

Bundy LM, Sealy L (CCAAT/enhancer binding protein beta (C/EBPbeta)-2 transforms normal mammary epithelial cells and induces epithelial to mesenchymal transition in culture. Oncogene 22:869-883.2003).

Carro MS, Lim WK, Alvarez MJ, Bollo RJ, Zhao X, Snyder EY, Sulman EP, Anne SL, Doetsch F, Colman H, Lasorella A, Aldape K, Califano A, Iavarone A (The transcriptional network for mesenchymal transformation of brain tumours. Nature 463:318-325).

Cortes-Canteli M, Luna-Medina R, Sanz-Sancristobal M, Alvarez-Barrientos A, Santos A, Perez-Castillo A (CCAAT/enhancer binding protein beta deficiency provides cerebral protection following excitotoxic injury. J Cell Sci 121:1224-1234.2008).

Cortes-Canteli M, Pignatelli M, Santos A, Perez-Castillo A (CCAAT/enhancer-binding protein beta plays a regulatory role in differentiation and apoptosis of neuroblastoma cells. J Biol Chem 277:5460-5467.2002).

Cortes-Canteli M, Wagner M, Ansorge W, Perez-Castillo A (Microarray analysis supports a role for ccaat/enhancer-binding protein-beta in brain injury. J Biol Chem 279:1440914417.2004).

DeAngelis LM (Brain tumors. N Engl J Med 344:114-123.2001).

Edwards E, Geng L, Tan J, Onishko H, Donnelly E, Hallahan DE (Phosphatidylinositol 3kinase/Akt signaling in the response of vascular endothelium to ionizing radiation. Cancer Res 62:4671-4677.2002).

El Andaloussi A, Sonabend AM, Han Y, Lesniak MS (Stimulation of TLR9 with CpG ODN enhances apoptosis of glioma and prolongs the survival of mice with experimental brain tumors. Glia 54:526-535.2006).

Fomchenko EI, Holland EC (Mouse models of brain tumors and their applications in preclinical trials. Clin Cancer Res 12:5288-5297.2006).

Hanlon M, Sealy L (Ras regulates the association of serum response factor and CCAAT/enhancer-binding protein beta. J Biol Chem 274:14224-14228.1999).

Hennig J, Nauerth A, Friedburg H (RARE imaging: a fast imaging method for clinical MR. Magn Reson Med 3:823-833.1986). 
Homma J, Yamanaka R, Yajima N, Tsuchiya N, Genkai N, Sano M, Tanaka R (Increased expression of CCAAT/enhancer binding protein beta correlates with prognosis in glioma patients. Oncol Rep 15:595-601.2006).

Kjaergaard J, Tanaka J, Kim JA, Rothchild K, Weinberg A, Shu S (Therapeutic efficacy of OX40 receptor antibody depends on tumor immunogenicity and anatomic site of tumor growth. Cancer Res 60:5514-5521.2000).

Li W, Kessler P, Yeger H, Alami J, Reeve AE, Heathcott R, Skeen J, Williams BR (A gene expression signature for relapse of primary wilms tumors. Cancer Res 65:25922601.2005).

Luna-Medina R, Cortes-Canteli M, Sanchez-Galiano S, Morales-Garcia JA, Martinez A, Santos A, Perez-Castillo A (NP031112, a thiadiazolidinone compound, prevents inflammation and neurodegeneration under excitotoxic conditions: potential therapeutic role in brain disorders. The Journal of neuroscience 27:5766-5776.2007).

Menard C, Hein P, Paquin A, Savelson A, Yang XM, Lederfein D, Barnabe-Heider F, Mir AA, Sterneck E, Peterson AC, Johnson PF, Vinson C, Miller FD (An essential role for a MEK-C/EBP pathway during growth factor-regulated cortical neurogenesis. Neuron 36:597-610.2002).

Miyatake S, Martuza RL, Rabkin SD (Defective herpes simplex virus vectors expressing thymidine kinase for the treatment of malignant glioma. Cancer Gene Ther 4:222228.1997).

Nadeau S, Hein P, Fernandes KJ, Peterson AC, Miller FD (A transcriptional role for C/EBP beta in the neuronal response to axonal injury. Mol Cell Neurosci 29:525-535.2005).

Paxinos G, Franklin K (2001) The mouse brain in stereotaxic coordinates. San Diego: Academic Press.

Pignatelli M, Cortes-Canteli M, Lai C, Santos A, Perez-Castillo A (The peroxisome proliferator-activated receptor gamma is an inhibitor of ErbBs activity in human breast cancer cells. J Cell Sci 114:4117-4126.2001).

Poli V (The role of C/EBP isoforms in the control of inflammatory and native immunity functions. J Biol Chem 273:29279-29282.1998).

Ramji DP, Foka P (CCAAT/enhancer-binding proteins: structure, function and regulation. Biochem J 365:561-575.2002).

Rask K, Thorn M, Ponten F, Kraaz W, Sundfeldt K, Hedin L, Enerback S (Increased expression of the transcription factors CCAAT-enhancer binding protein-beta (C/EBBeta) and C/EBzeta (CHOP) correlate with invasiveness of human colorectal cancer. Int J Cancer 86:337-343.2000).

Robinson GW, Johnson PF, Hennighausen L, Sterneck E (The C/EBPbeta transcription factor regulates epithelial cell proliferation and differentiation in the mammary gland. Genes Dev 12:1907-1916.1998).

Screpanti I, Romani L, Musiani P, Modesti A, Fattori E, Lazzaro D, Sellitto C, Scarpa S, Bellavia D, Lattanzio G, et al. (Lymphoproliferative disorder and imbalanced T-helper response in C/EBP beta-deficient mice. Embo J 14:1932-1941.1995). 
Schuster MB, Porse BT (C/EBPalpha: a tumour suppressor in multiple tissues? Biochim Biophys Acta 1766:88-103.2006).

Seagroves TN, Krnacik S, Raught B, Gay J, Burgess-Beusse B, Darlington GJ, Rosen JM (C/EBPbeta, but not C/EBPalpha, is essential for ductal morphogenesis, lobuloalveolar proliferation, and functional differentiation in the mouse mammary gland. Genes Dev 12:1917-1928.1998).

Sebastian T, Malik R, Thomas S, Sage J, Johnson PF (C/EBPbeta cooperates with RB:E2F to implement Ras(V12)-induced cellular senescence. EMBO J 24:3301-3312.2005).

Shuman JD, Sebastian T, Kaldis P, Copeland TD, Zhu S, Smart RC, Johnson PF (Cell cycledependent phosphorylation of C/EBPbeta mediates oncogenic cooperativity between C/EBPbeta and H-RasV12. Mol Cell Biol 24:7380-7391.2004).

Sterneck E, Johnson PF (CCAAT/enhancer binding protein beta is a neuronal transcriptional regulator activated by nerve growth factor receptor signaling. J Neurochem 70:24242433.1998).

Sterneck E, Zhu S, Ramirez A, Jorcano JL, Smart RC (Conditional ablation of C/EBP beta demonstrates its keratinocyte-specific requirement for cell survival and mouse skin tumorigenesis. Oncogene 25:1272-1276.2006).

Sundfeldt K, Ivarsson K, Carlsson M, Enerback S, Janson PO, Brannstrom M, Hedin L (The expression of CCAAT/enhancer binding protein (C/EBP) in the human ovary in vivo: specific increase in $\mathrm{C} / \mathrm{EBPbeta}$ during epithelial tumour progression. $\mathrm{Br} \mathrm{J}$ Cancer 79:1240-1248.1999).

Taubenfeld SM, Milekic MH, Monti B, Alberini CM (The consolidation of new but not reactivated memory requires hippocampal C/EBPbeta. Nat Neurosci 4:813-818.2001).

Tkac I, Starcuk Z, Choi IY, Gruetter R (In vivo 1H NMR spectroscopy of rat brain at $1 \mathrm{~ms}$ echo time. Magn Reson Med 41:649-656.1999).

Vinson CR, Sigler PB, McKnight SL (Scissors-grip model for DNA recognition by a family of leucine zipper proteins. Science 246:911-916.1989).

Wessells J, Yakar S, Johnson PF (Critical Prosurvival Roles for C/EBP\{ beta\} and Insulin-Like Growth Factor I in Macrophage Tumor Cells. Mol Cell Biol 24:3238-3250.2004).

Zagzag D, Miller DC, Chiriboga L, Yee H, Newcomb EW (Green fluorescent protein immunohistochemistry as a novel experimental tool for the detection of glioma cell invasion in vivo. Brain Pathol 13:34-37.2003).

Zhu S, Oh HS, Shim M, Sterneck E, Johnson PF, Smart RC (C/EBPbeta modulates the early events of keratinocyte differentiation involving growth arrest and keratin 1 and keratin 10 expression. Mol Cell Biol 19:7181-7190.1999).

Zhu S, Yoon K, Sterneck E, Johnson PF, Smart RC (CCAAT/enhancer binding protein-beta is a mediator of keratinocyte survival and skin tumorigenesis involving oncogenic Ras signaling. PNAS 99:207-212.2002). 


\section{FIGURE LEGENDS}

Figure 1. Expression of C/EBP $\beta$. (A) Western blot showing C/EBP $\beta$ expression in the glioblastoma murine cell line GL261 and in primary cultures of astrocytes in basal conditions and after $24 \mathrm{~h}$ of lipopolysaccharide (LPS) stimulation. Mouse primary astrocytes, were harvested and cultured as previously described (Luna-Medina et al., 2007). Cultures were stimulated with lipopolysaccharide (10 $\mu \mathrm{g} / \mathrm{ml}$, LPS) and cells were harvested $24 \mathrm{~h}$ later. (B) Expression of C/EBP $\beta$ in control $(\mathrm{C} 1, \mathrm{C} 2)$ and $\mathrm{C} / \mathrm{EBP} \beta$ depleted (I4, I5) GL261 pools, as assessed by Western blot analysis. The Westerns shown are representative of three different experiments. (C) Expression of C/EBP $\beta$ in control (FS) and C/EBP $\beta$-depleted (FC1) human LN18 cells. (D) Representative Western blot showing expression of C/EBP $\alpha$ and $\mathrm{C} / \mathrm{EBP} \delta$ in GL261 (C1 and I4) and LN18 (FS and FC1) cells.

Figure 2. Effect of C/EBP $\beta$ depletion on cell viability, proliferation, and clonogenicity. (A) C1, I4 and I5 pools were seeded into individual wells of a 96-well plate and cultivated for $24 \mathrm{~h}$ after which BrdU was added to the culture medium. Cells were harvested $16 \mathrm{~h}$ after BrdU addition. (B) Cells were grown on glass cover slips for $24 \mathrm{~h}$ and BrdU incorporation was analyzed $16 \mathrm{~h}$ after by immunofluorescence using a specific anti-BrdU antibody. Bar scale, $50 \mu \mathrm{m}$. Quantification of the results is shown in the right panel. Indicated is the percentage of $\mathrm{BrdU}^{+}$cells. (C) Murine $\mathrm{C} 1$ and $\mathrm{I} 4$ and human FS and FC1 cells were seeded in a 96-well plate and at different times after plating cell viability was determined by the MTT assay. (D) Progression through the cell cycle was analyzed by PI staining and FACS analysis. Curves modeling the G0/G1, $\mathrm{S}$, and G2/M compartment, derived by using the Summit program, are shown. Data are representative of three independent experiments. (E) Three weeks after seeding the cells in soft agar, 10 randomly selected microscopic fields were counted. Shown are representative microphotographs (bar scale $250 \mu \mathrm{m}$ ) and quantification. Values in panels $\mathrm{A}, \mathrm{B}, \mathrm{C}$ and $\mathrm{E}$ represent the means \pm S.D. of at least three different experiments.

Figure 3. Effects of C/EBP $\beta$ on cell motility and invasion. (A) Murine $\mathrm{C} 1$ and $\mathrm{I} 4$ and human FS and FC1 cells were grown to confluence into a monolayer and a linear scratch wound was performed with a plastic pipette tip. Images were taken with a phase 
contrast microscope at different times after wounding. Representative phase-contrast images of the in vitro wound-healing assay are shown. Bar scale, $100 \mu \mathrm{m}$ (B) Cell invasion was measured on transwell coated with Matrigel as described in Materials and Methods. Values are represented as means \pm S.D. of three different experiments.

Figure 4. Western blot analysis. Protein lysates from C1, I4, and I5 pools were used for western blot analysis using specific antibodies against ATM, chk2, Brca1, and p27, as indicated in Materials and Methods.

Figure 5. Effects of C/EBP $\beta$ expression on tumor growth in vivo. Histological and immunostaining analysis of tumors induced by GL261-derived pools. (A) $T_{1}$ magnetic resonance imaging (MRI) pictures obtained from mice injected with the GL261-derived clones. $\mathrm{T}_{1}$-weighted imaging was performed at 7 Tesla as described in Materials and Methods at different times after injection. Cortical images showing the brains of representative mice, obtained at 11, 15, and 18 days post-injection are presented. (B) Quantitative analysis of total tumor volumes. Values represent the mean \pm S.D. from five different animals. (C) Kaplan-Meier plots and log-rank statistics analysis of overall survival reveal that downregulation of $\mathrm{C} / \mathrm{EBP} \beta$ expression in $\mathrm{I} 4$ tumors significantly improves survival of tumor-bearing mice compared with their $\mathrm{C} 1$ controls (log-rank test $p=0.0012$ ). (D) Representative hematoxylin and eosin staining images of the C1- and I4-derived tumors. Middle and right panels show higher magnifications of the images shown in the two left panels. C1 tumors showed clear blood vessels (arrows) and multinuclear giant cells (arrowheads). Scale bars, $100 \mu \mathrm{m}$ (E) Immunocytochemistry analysis of tumor sections for PCNA detection. Scale bar, $25 \mu \mathrm{m}$.

Table I. Effect of C/EBPß on cancer regulatory gene expression. 
Figure 1

A

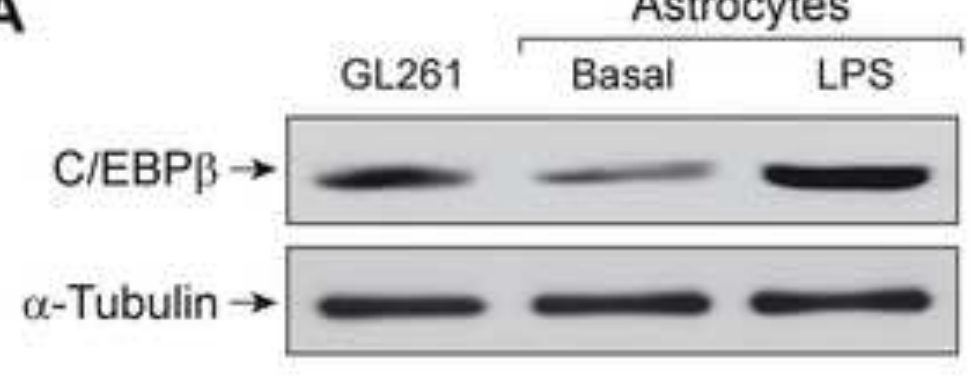

C

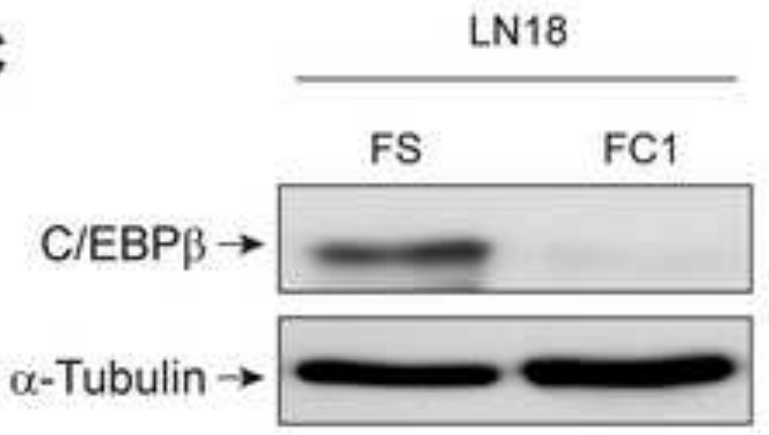

B

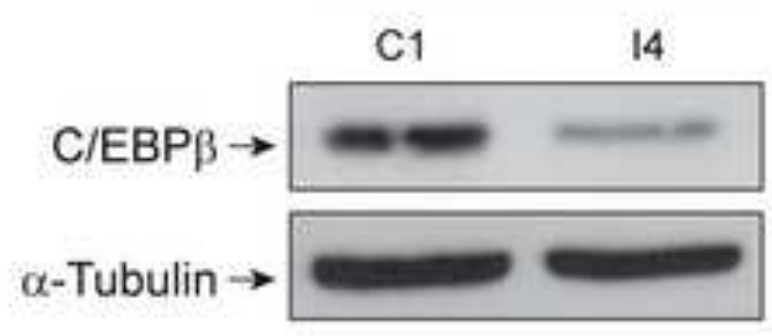

GL261

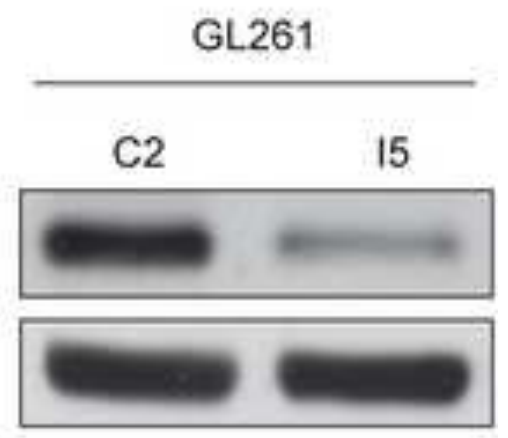

D

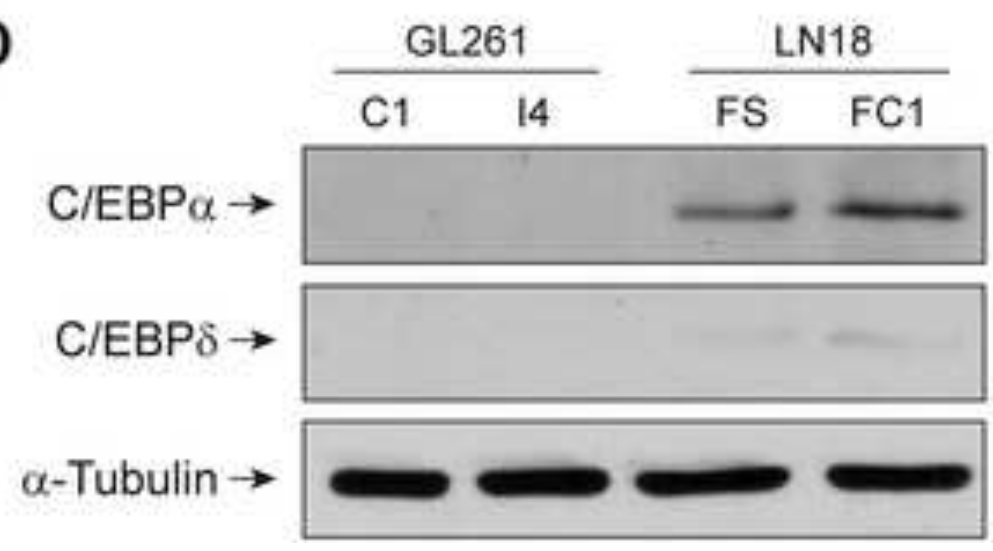


Figure 2
Click here to download high resolution image

Figure 2

A

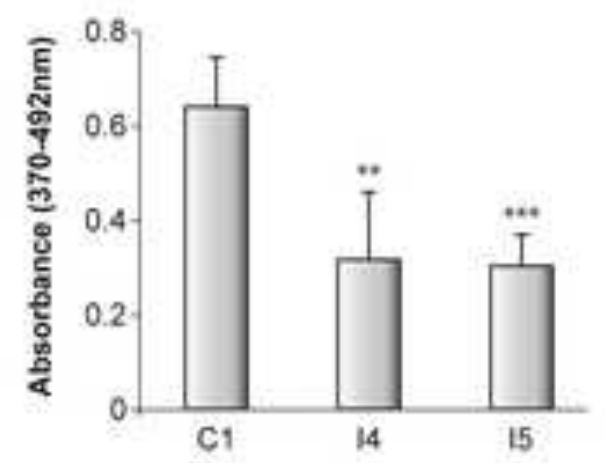

C

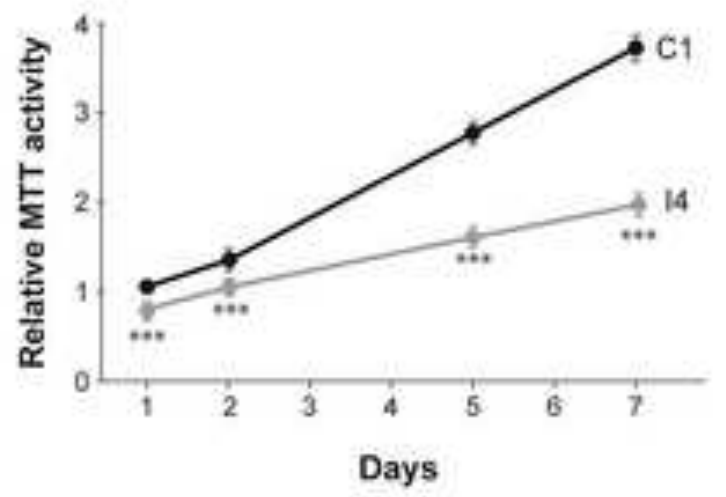

D

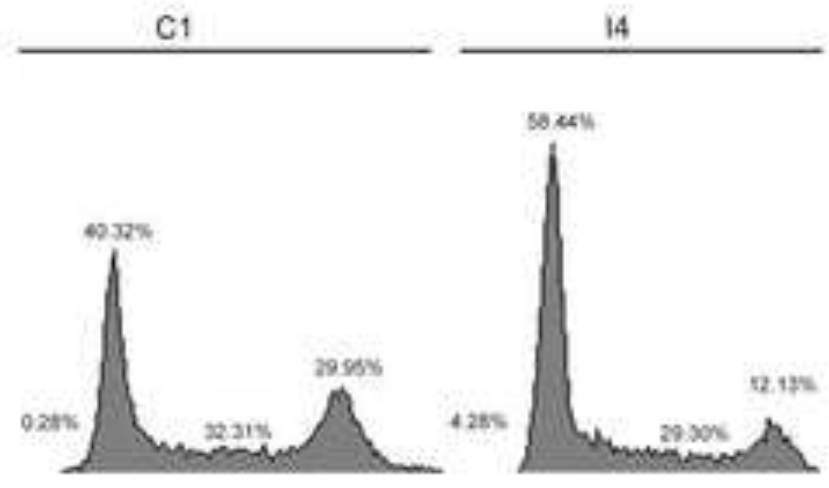

B

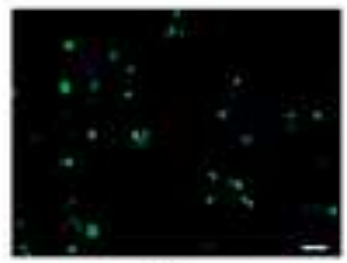

C1

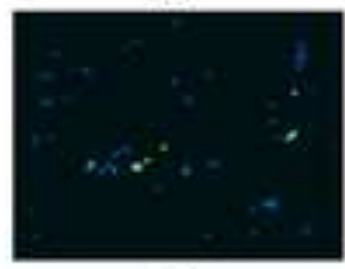

14

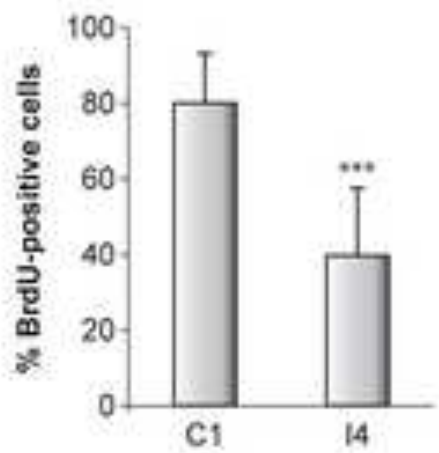

E

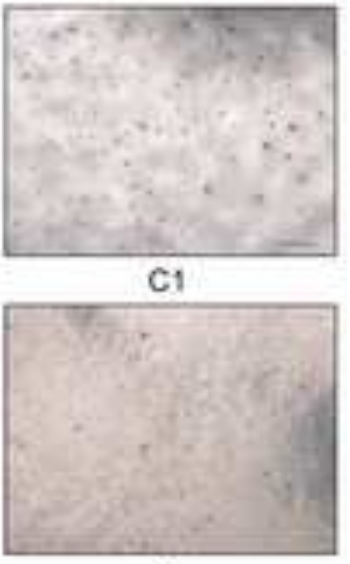

14

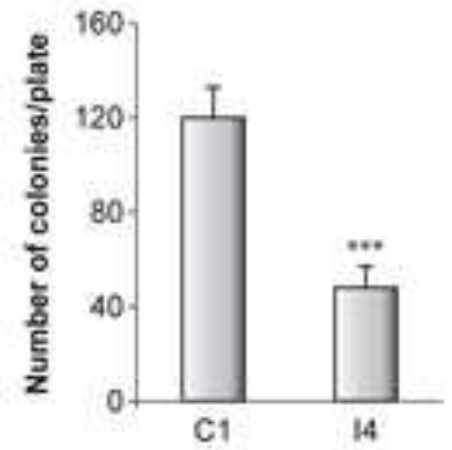


Figure 3

Click here to download high resolution image

Figure 3

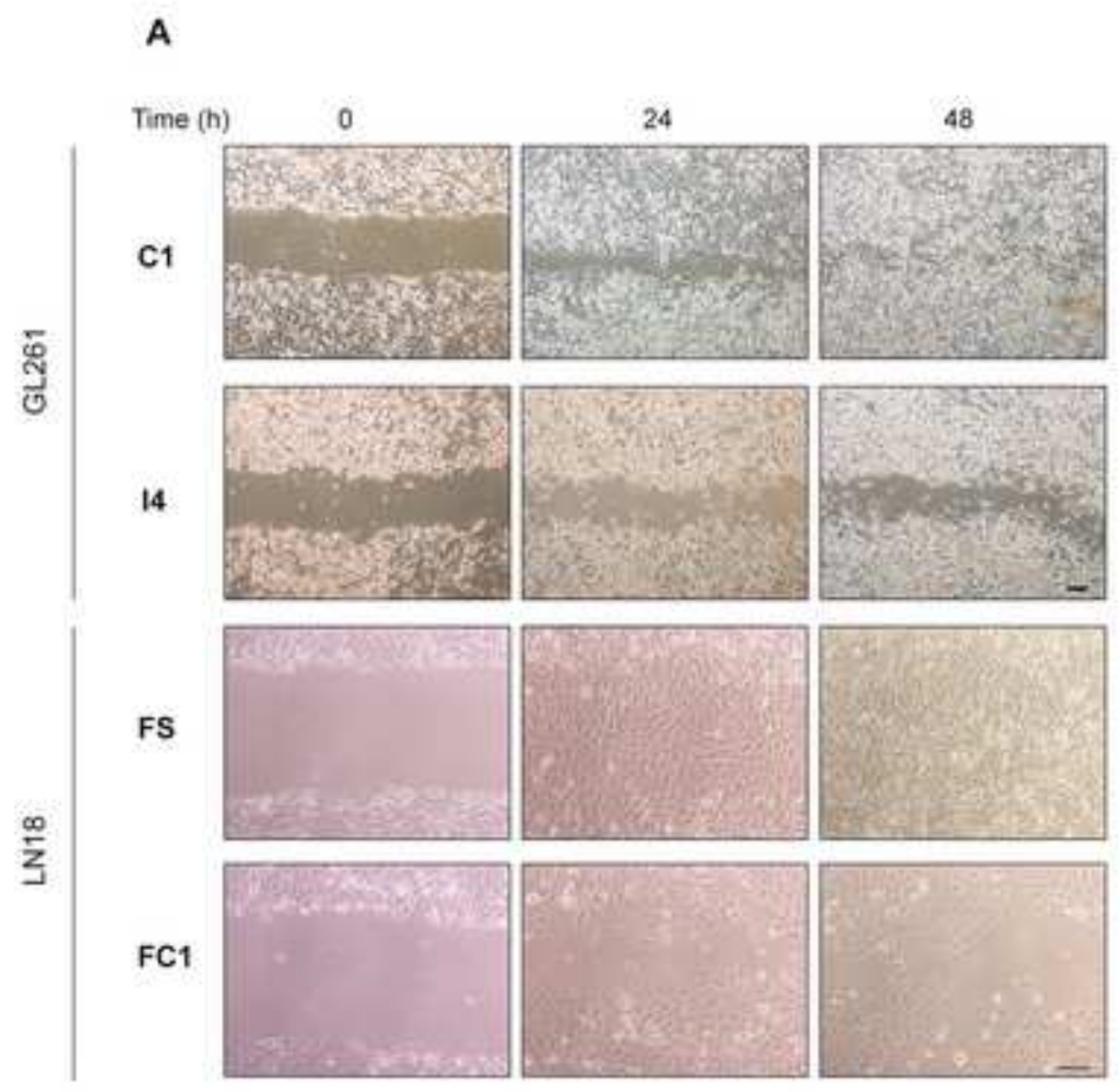

B
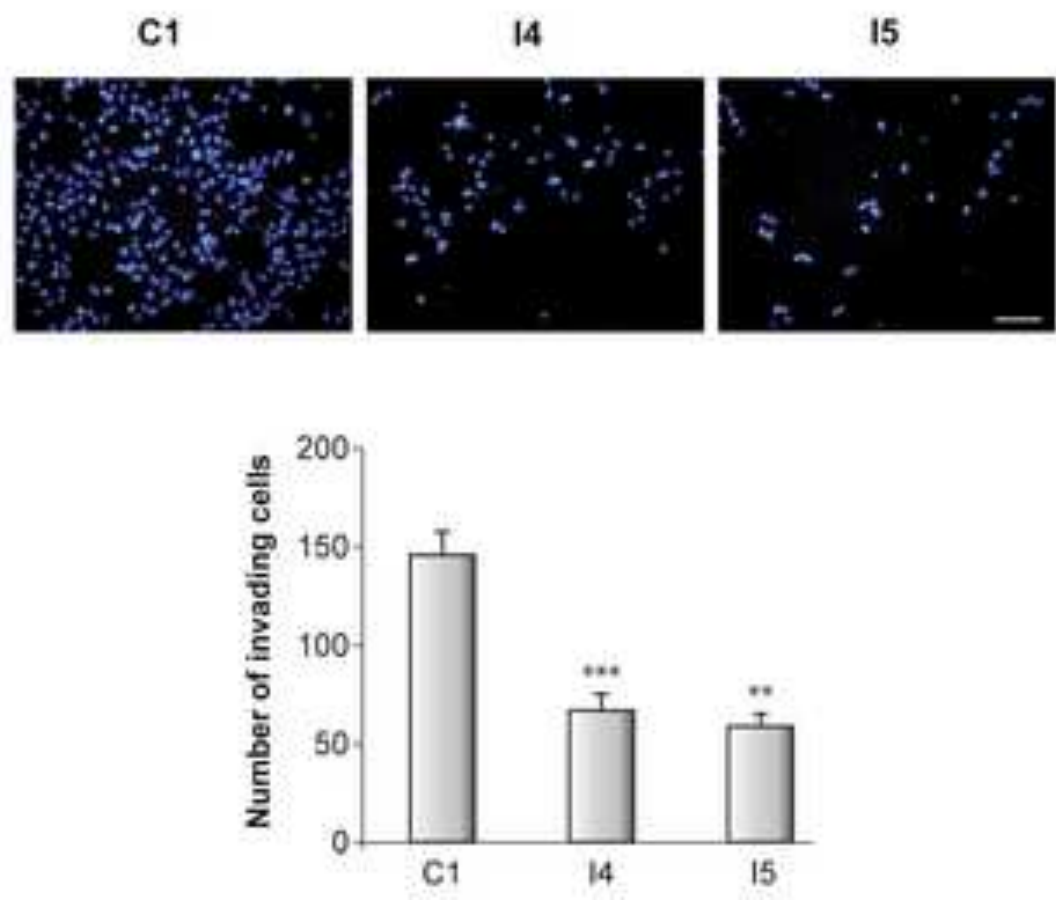
Figure 4
Click here to download high resolution image

Figure 4

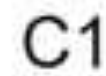

14

15
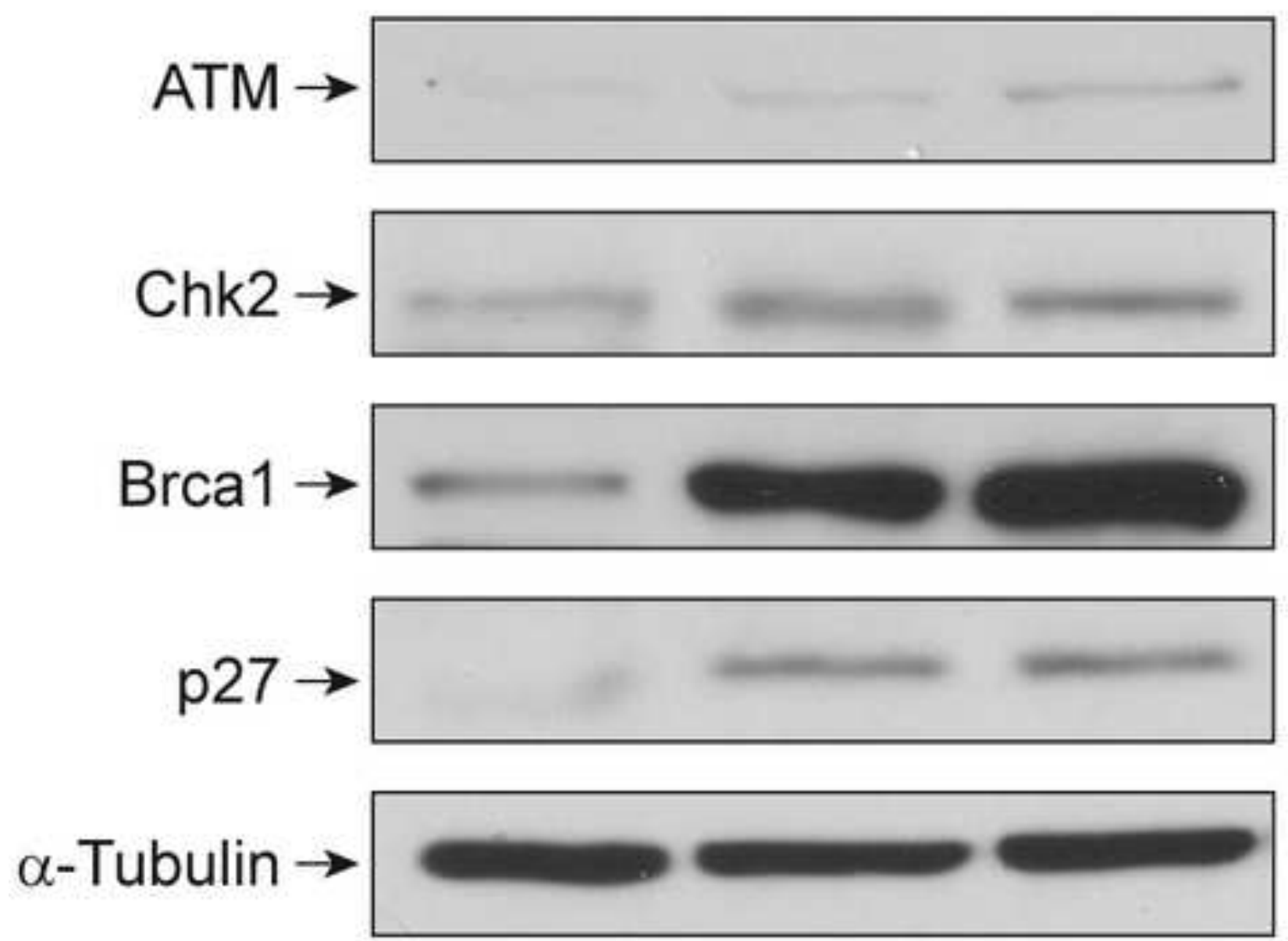
Figure 5

Click here to download high resolution image

Figure 5

A

Days after ic injection
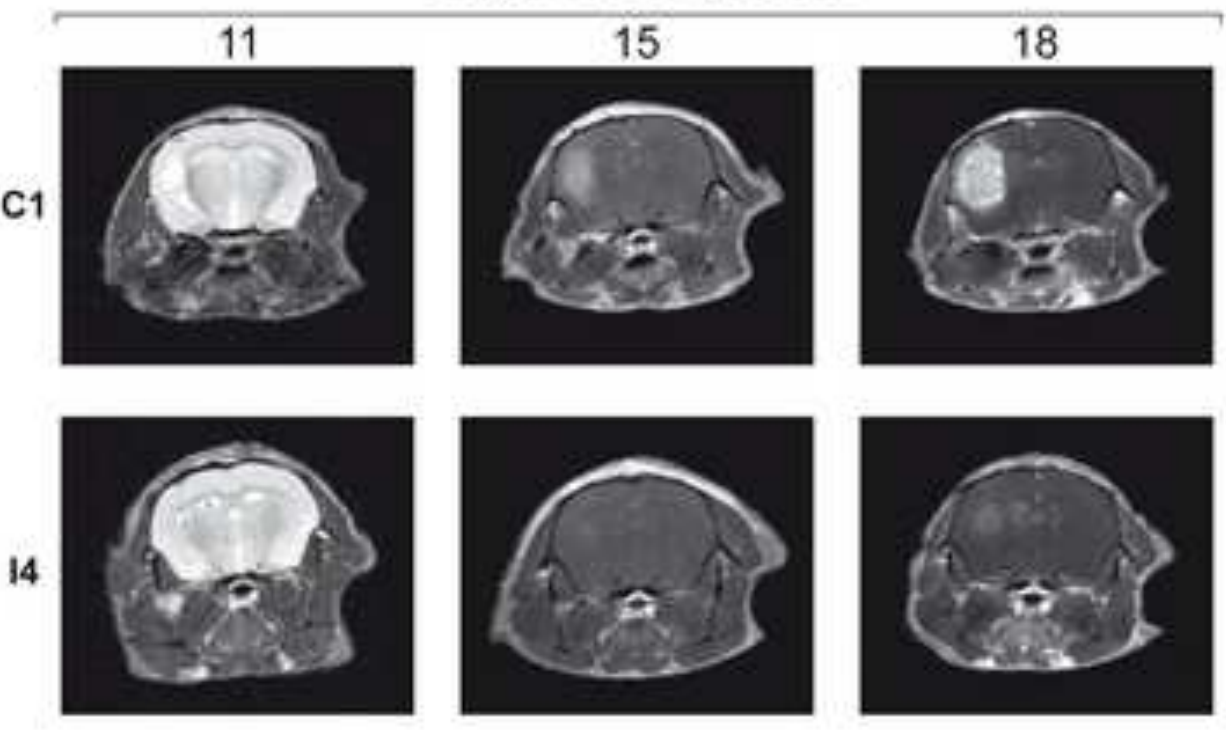

B

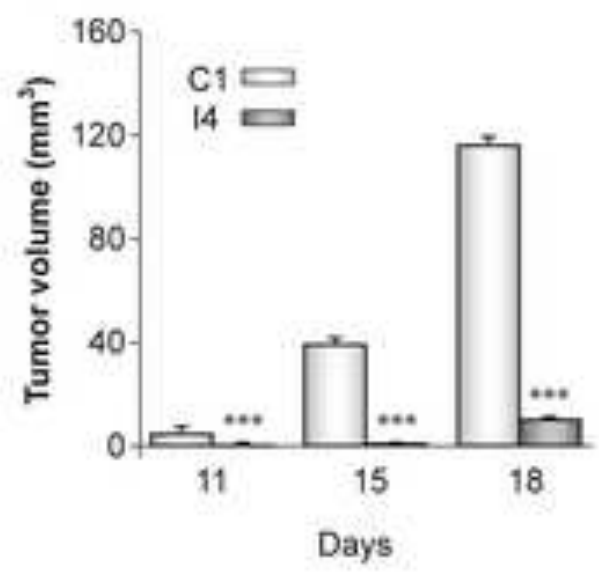

C

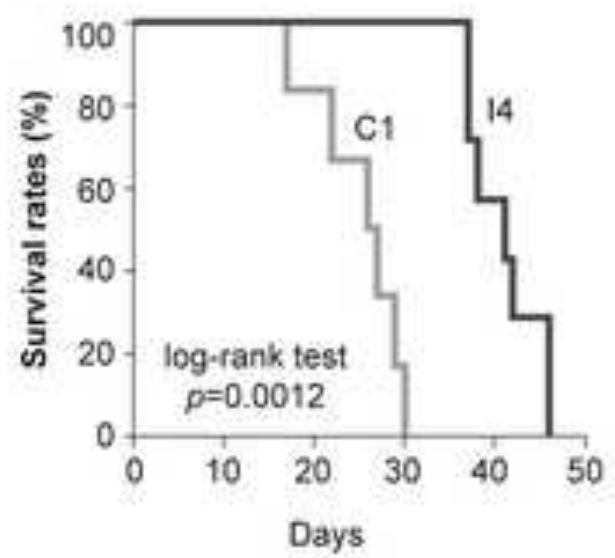

D H\&E

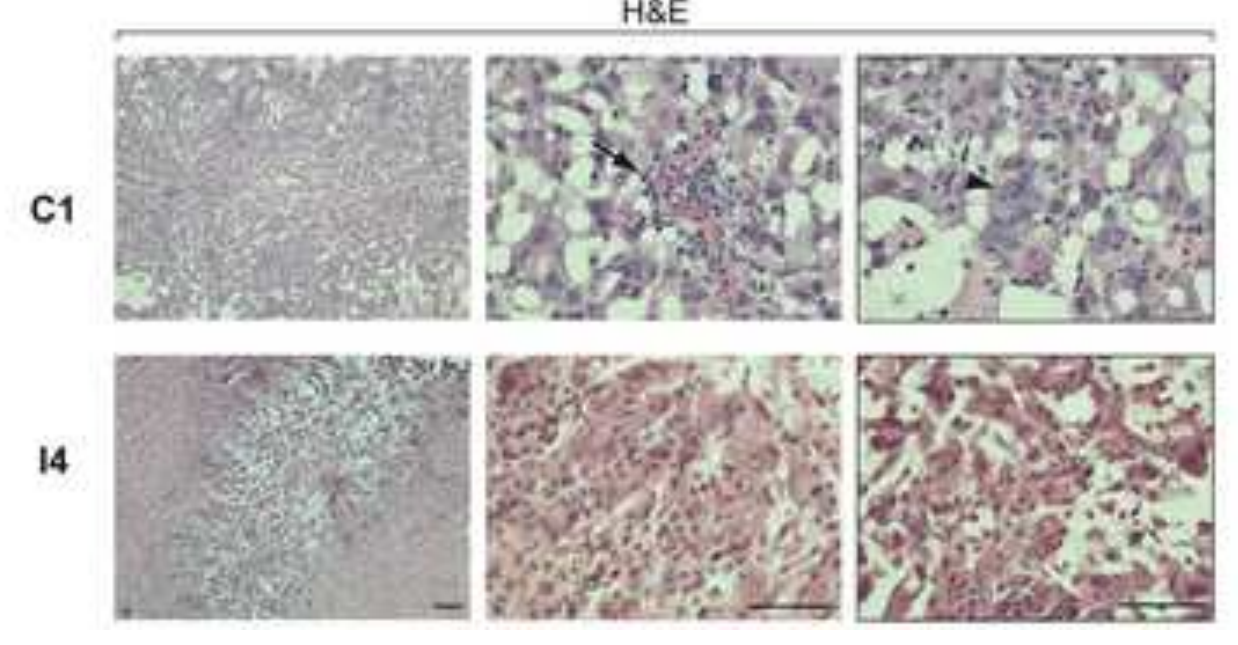

E
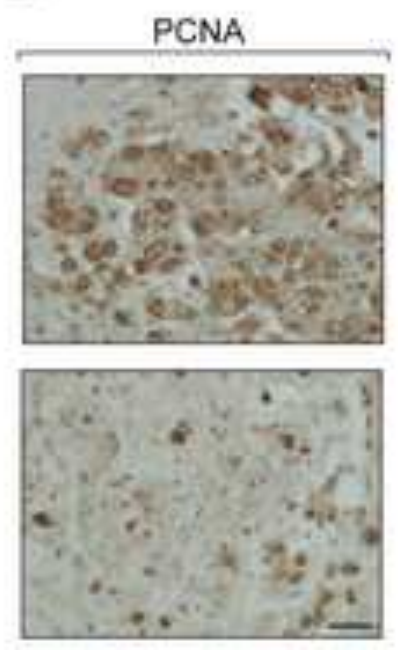
Table I. Effect of C/EBP $\beta$ on cancer regulatory gene expression

\section{mRNA}

Apaf1 (Apoptotic peptidase activating factor 1)

Atm (Ataxia Telangiectasia Mutated)

Brca1 (Breast Cancer 1)

Brca2 (Breast Cancer 2)

Cdkn1b (Cyclin-dependent kinase inhinitor 1B, p27)

Chek1 (Checkpoint kinase 1)

Chek2 (Checkpoint kinase 2)

Itga3 (Integrin alpha 3)

Itgb3 (Integrin beta 3)

Mcam1 (Melanoma cell adhesion molecule)

Plaur (Plasminogen activator, urokinase receptor)

S100A4 (S100 Calcium binding protein A4)

Vegfc (Vascular endothelial growth factor C)

\section{4/C1}

(mean of fold change)

4.82

6.41

1.91

6.45

3.51

3.46

1.61

0.40

0.32

0.53

0.47

0.04

0.50 